\title{
First record of entomopathogenic nematodes from Yucatán State, México and their infectivity capacity against Aedes aegypti
}

\author{
Mariana B Ávila-López ${ }^{\text {Corresp., } 1}{ }^{2}$, José Q García-Maldonado ${ }^{2}$, Héctor Estrada-Medina ${ }^{3}$, David I Hernández-Mena ${ }^{1}$, \\ Daniel Cerqueda-García ${ }^{1}$, Víctor M Vidal-Martínez ${ }^{\text {Corresp. } 1}$ \\ ${ }^{1}$ Aquatic Pathology Laboratory. Centro de Investigación y de Estudios Avanzados del Instituto Politécnico Nacional Unidad Mérida, Carretera Antigua a \\ Progreso,, Mérida, Yucatán, México \\ ${ }^{2}$ CONACYT - Centro de Investigación y de Estudios Avanzados del Instituto Politécnico Nacional, Unidad Mérida. Departamento de Recursos del Mar, \\ Mérida, Yucatán, México \\ 3 Facultad de Medicina Veterinaria y Zootecnia, Departamento de Manejo y Conservación de Recursos Naturales Tropicales, Campus de Ciencias \\ Biológicas y Agropecuarias, Universidad Autónoma de Yucatán, Mérida, Yucatán, México., Merida, Yucatan, México \\ Corresponding Authors: Mariana B Ávila-López, Víctor M Vidal-Martínez \\ Email address: marianab.avila@cinvestav.mx, vvidal@cinvestav.mx
}

Background. Biological control using entomopathogenic nematodes (EPN) has demonstrated good potential to contribute to the integral control of mosquito larvae, which as adults are vectors of diseases such as Dengue fever, Zika and Chikungunya. However, until now there are no records of the presence of EPN or their killing capacity in Yucatán state, southern México. The objectives of the current study were: 1) to report the entomopathogenic nematodes present in Yucatán soils and 2) to determine the killing capacity of the most frequent and abundant EPN against Aedes aegypti mosquito larvae and the microbial community developed by Ae. Aegypti exposed to this EPN. Methods. The nematodes were collected by the insect trap technique using the great wax moth Galleria mellonella. Internal transcribed spacer (ITS), 28S gene of ribosomal DNA and phylogenetic analyses were performed to identify the EPN. For the bioassay, four concentrations of the most frequent and abundant EPN were tested: 1260:1 infective juveniles (IJs) per mosquito larvae, $2520 \mathrm{lJs}: 1,3780 \mathrm{lJs}: 1$ and $5040 \mathrm{lJs}: 1$. High-throughput sequencing of the $16 \mathrm{~S}$ rRNA gene was used to identify bacterial amplicon sequences in the mosquito larvae infected with EPN. Results. Six isolates of Heterorhabditis were recovered from 144 soil samples. Heterorhabditis indica (four isolates) was the most frequent and abundant EPN, followed by Heterorhabditis n. sp. (two isolates). Both nematodes are reported for the first time for Yucatán state, Mexico. The concentration of $2520 \mathrm{IJs}: 1$ produced $80 \%$ of mosquito larvae mortality in $48 \mathrm{~h}$. Representative members of Photorhabdus genus were numerically dominant (74\%) in mosquito larvae infected by $H$. indica. It is most likely that these bacteria produce secondary toxic metabolites that enhance the mortality of these mosquito larvae.

Peer] reviewing PDF | (2021:03:58801:1:1:NEW 13 May 2021) 
1 First record of entomopathogenic nematodes from Yucatán State, México and

2 their infectivity capacity against Aedes aegypti

3 Mariana B. Ávila-López ${ }^{1}$, José Q. García-Maldonado ${ }^{2}$, Héctor Estrada-Medina ${ }^{3}$, David I.

4 Hernández-Mena ${ }^{1}$, Daniel Cerqueda-García ${ }^{1}$, and Víctor M. Vidal-Martínez ${ }^{\text {* }}$

5

$6 \quad{ }^{1}$ Aquatic Pathology Laboratory. Centro de Investigación y de Estudios Avanzados del Instituto

7 Politécnico Nacional Unidad Mérida, Carretera Antigua a Progreso, Km. 6, Mérida, Yucatán,

8 C.P. 97310. México.

$9 \quad{ }^{2}$ CONACYT - Centro de Investigación y de Estudios Avanzados del Instituto Politécnico

10 Nacional, Unidad Mérida. Departamento de Recursos del Mar, Mérida, Yucatán, México.

$11{ }^{3}$ Facultad de Medicina Veterinaria y Zootecnia, Departamento de Manejo y Conservación de

12 Recursos Naturales Tropicales, Campus de Ciencias Biológicas y Agropecuarias, Universidad

13 Autónoma de Yucatán, Mérida, Yucatán, México. Correspondence should be sent to:

14 vvidal@cinvestav.mx

15

16

17

18

19 


\section{ABSTRACT:}

22 Background. Biological control using entomopathogenic nematodes (EPN) has demonstrated

23 good potential to contribute to the integral control of mosquito larvae, which as adults are vectors

24 of diseases such as Dengue fever, Zika and Chikungunya. However, until now there are no

25 records of the presence of EPN or their killing capacity in Yucatán state, southern México. The

26 objectives of the current study were: 1) to report the entomopathogenic nematodes present in

27 Yucatán soils and 2) to determine the killing capacity of the most frequent and abundant EPN

28 against Aedes aegypti mosquito larvae and the microbial community developed by Ae. Aegypti

29 exposed to this EPN. Methods. The nematodes were collected by the insect trap technique using

30 the great wax moth Galleria mellonella. Internal transcribed spacer (ITS), 28S gene of ribosomal

31 DNA and phylogenetic analyses were performed to identify the EPN. For the bioassay, four

32 concentrations of the most frequent and abundant EPN were tested: 1260:1 infective juveniles

33 (IJs) per mosquito larvae, $2520 \mathrm{IJs}: 1,3780 \mathrm{IJs}: 1$ and $5040 \mathrm{IJs}$ :1. High-throughput sequencing of

34 the 16S rRNA gene was used to identify bacterial amplicon sequences in the mosquito larvae

35 infected with EPN. Results. Six isolates of Heterorhabditis were recovered from 144 soil

36 samples. Heterorhabditis indica (four isolates) was the most frequent and abundant EPN,

37 followed by Heterorhabditis n. sp. (two isolates). Both nematodes are reported for the first time

38 for Yucatán state, Mexico. The concentration of 2520 IJs:1 produced 80\% of mosquito larvae

39 mortality in $48 \mathrm{~h}$. Representative members of Photorhabdus genus were numerically dominant

$40(74 \%)$ in mosquito larvae infected by $H$. indica. It is most likely that these bacteria produce

41 secondary toxic metabolites that enhance the mortality of these mosquito larvae.

42 Keywords: Aedes aegypti, biological control, Galleria mellonella, Heterorhabditis indica,

43 Photorhabdus, 16S rRNA 


\section{Introduction}

Biological control using entomopathogenic nematodes (EPN) has demonstrated good potential to

47 contribute to the integral control of pests of agricultural and medical importance (Chitra et al., 2017). In the case of nematodes of the families Steinernematidae and Heterorhabditidae, their killing capacity is based on their symbiotic relationship with bacteria of the genera Xenorhabdus and Photorhabdus, as well as on their capacity to infect insect hosts. During the EPN life cycle, the infective juvenile (IJs) enters the host's body through natural openings such as mouth, anus and spiracles. Steinernema can even penetrate the insect's integument (Peters, 1994; Peters \& Ehlers, 1997). In the case of Heterorhabditis, this is done with the help of a cuticule projection resembling a tooth. Some authors even speak about a dorsal tooth (e.g. Nguyen et al., 2004). Once inside the host, the IJs migrate to the hemocoel where they release their symbiont bacteria (Bedding, Akhurst \& Kaya, 1993). The bacterial community produces secondary metabolites with cytotoxic, antimicrobial, antiparasitic and insecticide activity, causing septicaemia in a period of 24 to 48 hours after infection (Bode, 2009). These nematodes feed on the host tissues and reproduce for two or three generations, depending on the availability of food resources and the size of the host (San-Blas, Gowen \& Pembroke, 2008). Then, the free-living stage IJs

61 migrate, looking for another insect host to parasitise (Akhurst, 1993).

62 The monoxenic relationships between Steinernema-Xenorhabdus and Heterorhabditis-

63 Photorhabdus have been frequently tested (Eivazian, Mohammadi \& Girling, 2017), although

64 bacteria such as Providencia sp., Ochrobactrum sp., Pseudomonas sp., and Alcaligenes faecalis

65 have also been isolated from EPNs, without a clear understanding of their role in such

66 interactions (Jackson et al., 1995; Babic et al., 2000; Gouge \& Snyder, 2006). In insects, most 
67 microbiota studies have been based on the intestinal bacterial or haemolymph composition of

68 infected insects (Engel \& Moran, 2013). Indeed, diaxenic associations of non-canonical bacteria

69 such as Pseudomonas aeruginosa have been found in the IJs of different generations of $H$.

70 indica, favouring the infection of hosts such as Galleria mellonella, Tenebrio molitor, Heliothis

71 subflexa, and Diatraea magnifactella when were combined with Photorhabdus luminescens

72 (Salgado-Morales et al., 2019).

73 During the last few years, several studies have focused on the isolation of native EPN as

74 biological control tools to fight against mosquitoes that may transmit important human diseases,

75 such as dengue, Zika, Chikungunya and yellow fever (Kovendan et al., 2018). Recently,

76 Dilipkumar et al. (2019) isolated Steinernema siamkayai, Heterorhabditis indica, Steinernema

77 glaseri and Steinernema abbasi and evaluate their biocontrol potential against Aedes aegypti,

78 Anopheles stephensi and Culex quinquefasciatus larvae. In the same way, in Thailand,

79 Yooyangket et al. (2018) evaluated larvicidal activity of symbiotic bacteria belonging to EPN

80 against Ae. aegypti and Ae. albopictus larvae. In Mexico, there are very few reports of native

81 EPNs. For example, Girón et al. (2012) isolated Heterorhabditis mexicana, Steinernema

82 carpocapsae and Steinernema feltiae from of Oaxaca soils. In Sonora, Stock, Rivera-Orduño \&

83 Flores-Lara, (2009) isolated Heterorhabditis sonorensis (currently, Heterorhabditis taysearae;

84 Dhakal et al., 2020) in nymph corpses of Diceroprocta ornea (Homoptera: Cicadidiae) in

85 asparagus crops. Most of the EPN isolated in Mexico have been tested for the biological control

86 of pests of agricultural importance (Stock, Rivera-Orduño \& Flores-Lara 2009; Salgado-

87 Morales et al., 2019).

88 Mexico also has a very important problem with the insidious capacity of Ae. aegypti for

89 transmitting viral diseases such as dengue fever, with 268,458 cases in 2019 
90 (https://www.paho.org/data/index.php/en/mnu-topics/indicadores-dengue-en/dengue-nacional-

91 en/252-dengue-pais-ano-en.html?). The official actions to control the vector spread have been

92 the elimination of breeding grounds and the use organophosphate and organochlorine pesticides.

93 However, an important drawback of these compounds is that they cause alterations to the

94 nervous, immunological, respiratory, endocrine and reproductive systems of humans, not to

95 mention resistance and persistence related to the environment (Blair et al., 2014). In rural and

96 urban zones, the use of such pesticides represents the main cause of groundwater pollution

97 (Olvera et al., 2008). Polanco et al. (2015) reported on the presence of organochlorine pesticides

98 like DDT at a concentration of 16 ppb in the aquifer of the Yucatán state, Cenotes Ring. Because

99 of this, it is extremely important to look for other environmentally friendly alternatives to control

100 the Ae. aegypti vector life cycle and one of these alternatives are the EPNs.

101 Our quest for EPN in the Yucatán revealed the presence of two species. Since EPNs are

102 pathogenic to insects, we hypothesise that the most frequent and abundant species (H. indica)

103 should be able to produce high mortality (> 70\%) in Ae. aegypti mosquito larvae. Under this

104 context, the purpose of the current study was two-fold: 1) to report for the first time the presence

105 of two species of entomopathogenic nematodes from Yucatán state soils, and 2) to determine the

106 killing capacity and microbial community present in $H$. indica against Ae. aegypti mosquito

107 larvae.

108

109

2. Materials \& Methods

110 During September and October 2018 (rainy season), soil samples were collected from 12

111 different locations of Yucatán state appertaining to the municipalities of Peto, Cantamayec, 
112 Tikuch, Cansahcab, Dzan, Sucila, Maxcanu, Opichen, Muna, Oxkutzcab, Tunkas and

113 Chikindzonot (Figure 1). Soil samples were collected from different cultivations of sour orange

114 (Citrus aurantium) and sweet orange (Citrus sinensis). To obtain the EPN, four composite soil

115 samples per location were used; these samples were placed in plastic containers ( $1 \mathrm{~kg}$ per flask)

116 for a total of 144 samples. Each flask was punched in the bottom and before taking the sample

117 from each flask, $15 \mathrm{~cm}$ were excavated using a small blade (Thanwisai et al., 2012). At the end

118 of the collection, the soil samples were placed in foam coolers for transportation to the Aquatic

119 Pathology Laboratory of the Centre for Research and Advanced Studies of the National

120 Polytechnic Institute (Mérida Unit). Galleria mellonella cultured in the laboratory were used as

121 insect traps for the EPN isolation (Bedding \& Akhurst, 1975). Four G. mellonella larvae per flask

122 were used and placed at room temperature for five days. The infected G. mellonella were placed

123 in wet chambers until the IJ emergence, following the procedure suggested by Kaya and Stock

124 (1997).

125

126

127 2.1. Soil analysis

128 A soil compound sample (four subsamples of $250 \mathrm{~g}$ each) was separated, weighed and labelled

129 for physico-chemical analysis. The samples were processed at the Soil, Plant and Water Analysis

130 Laboratory at the Universidad Autónoma de Yucatán (UADY), following a standard

131 measurement procedure: particle size with densimeter (Gee \& Bauder, 1986); redox and pH

132 through a potentiometer (Patrick, Gambrell \& Faulkner 1996; Thomas, 1996); phosphorous by

133 the Olsen method (Kuo, 1996); organic matter by colorimetric determination (Nelson \& 
134 Sommers, 1996) and electric conductivity through potentiometry (Rhoades, 1996). Student's $t$ -

135 test was used to determinate differences of physico-chemical characteristics between EPN

136 positive and EPN negative soil samples $(\mathrm{p} \leq 0.05)$.

137

138 2.2. Polymerase chain reaction and sequencing of EPNs

139 For DNA extraction, two adult nematodes were cut into small pieces using a sterile scalpel to

140 reduce cell lysis time according to the protocol of the DNeasy Blood and Tissue kit (Qiagen ${ }^{\mathrm{TM}}$ ).

141 The ITS region and the 28S gene of ribosomal DNA were amplified by the polymerase chain

142 reaction (PCR). For the PCR mix in each tube we added the follow: $12.5 \mu 1$ of Green GoTaq

143 Master Mix (Promega, Madison, WI, USA), $1 \mu 1$ of each primer $(10 \mu \mathrm{m}), 8.5 \mu 1$ of distilled

144 water and $2 \mu 1$ of genomic DNA for a final volume of $25 \mu 1$. The primers used in this study for

145 ITS were the forward TW81 5-GTTTCCGTAGGTGAACCTGC-3, plus the reverse AB28 5-

146 ATATGCTTAAGTTCAGCGGGT-3 (Nthenga et al., 2014). For the 28S rRNA gene, the

147 primers used were 391F 5'-AGCGGAGGAAAAGAAACTAA-3' (Nadler \& Hudspeth, 1998)

148 and 536R 5'-CAGCTATCCTGAGGGAAAC-3' (García-Varela \& Nadler, 2005). All PCR

149 reactions were run in an Axygen ${ }^{\circledR}$ MaxyGene ${ }^{\mathrm{TM}}$ II thermocycler. For ITS, the following

150 amplification conditions were used: one cycle of pre-denaturation at $94^{\circ} \mathrm{C}$ for 5 min, followed by

15135 cycles of denaturation at $92^{\circ} \mathrm{C}$ for 30 seconds, annealing at $47^{\circ} \mathrm{C}$ for 45 seconds, extension at

$15272^{\circ} \mathrm{C}$ for 90 seconds and finally an extension at $72^{\circ} \mathrm{C}$ for 10 minutes. Subsequently, the

153 following amplification conditions were used for the 28S PCR: one cycle of pre-denaturation at

$15494^{\circ} \mathrm{C}$ for $5 \mathrm{~min}$, followed by 35 cycles of denaturation at $94^{\circ} \mathrm{C}$, annealing at $50^{\circ} \mathrm{C}$, and extension

155 at $72^{\circ} \mathrm{C}$ for 1 minute each temperature and, then a final extension at $72^{\circ} \mathrm{C}$ for 10 minutes. PCR

156 products were verified by electrophoresis on a 1\% agarose gel using $1 \mathrm{X}$ TAE buffer at $90 \mathrm{~V}$ for 
15745 min in a BioRad Sub-Cell ${ }^{\circledR}$ GT agarose gel electrophoresis system using a Promega ${ }^{\circledR}$ DNA

158 leader of $1 \mathrm{~KB}$ molecular weight as a reference. The PCR products were visualised in a BioDoc-

159 It® Imager. PCR products were commercially sequenced by GENEWIZ (South Plainfield, NJ,

160 USA). Subsequently, the consensus sequences of ITS and 28S were aligned with the sequences

161 obtained for each primer using Geneious Pro 4.8.4® (Biomatters Ltd.). The consensus sequences

162 of each nematode were deposited in the GenBank database with accession numbers MW729401

163 to MW729412 (Fig. 2).

164

165 2.3. Phylogenetic analysis of EPNs

166 For the identification of the EPN that in both cases belonged to the genus Heterorhabditis, the

167 consensus sequences of ITS and 28S rRNA gene of our specimens were subjected to BLAST

168 (Altschul et al., 1990) alignment against the nucleotide database at National Centre for

169 Biotechnology Information (NCBI). Subsequently, the sequences generated in this study were

170 aligned with sequences available in GenBank belonging to other species of Heterorhabditis. Two

171 datasets were generated, one for ITS and another for 28S. Heterorhabditidoides was used as

172 outgroup. The alignment of each data set was performed with ClustalW (Thompson, Higgins \&

173 Gibson, 1994), implemented in the website http://www.genome.jp/tools/clustalw/, with the

174 approach 'SLOW/ACCURATE' and weight matrix 'CLUSTALW (FOR DNA)'. The extremes

175 of the alignment were trimmed to match the length of our sequences. The nucleotide substitution

176 model was estimated with the program jModelTest v2 (Darriba et al., 2012). Phylogenetic

177 analysis was run under Maximum Likelihood (ML) with RAxML v. 7.0.4 (Stamatakis, 2006). A

178 first phylogenetic analysis was performed with Raxml to discard sequences of GenBank that may 
179 have problems of taxonomic identification in each data set. Then, a second phylogenetic analysis

180 was performed with 10 replicates and 1,000 bootstrap repetitions to obtain the best phylogenetic

181 hypothesis of the ITS and 28S datasets. The ML trees were visualised in FigTree v.1.4.3.

182 (Rambaut, 2016). Molecular variation of 28S data sets was estimated using uncorrected $\mathrm{p}$

183 distances (p-distances) with the software MEGA v.6 (Tamura et al., 2013).

184

185 2.4. Experimental infection

186 For the assays we used the most frequent and abundant entomopathogenic nematode species

187 recovered from the G. mellonella infections, i.e. H. indica. We used flasks with a capacity of 1.9

188 litres with $400 \mathrm{ml}$ of bubbled tap water, and the following procedure. Four concentrations of

189 nematodes were used: 1:1,260 mosquito larvae/infective juveniles [1/[IJs])., 1: 2,520 1/IJs, 1:

1903,780 1/IJs, 1: 5,040 1/IJs and a control per concentration (mosquito larvae without nematodes)

191 with each concentration replicated four times. Each treatment and control flask contained ten $A e$.

192 aegypti larvae in the fourth stage. The experimental infection was replicated two times, with very

193 similar results (Fig. S1 presents mosquito larvae survival in the first experiment). Consequently,

194 we only present the outcomes of the last experimental infection. The Ae. aegypti eggs were

195 raised in the Laboratory of Aquatic Pathology of the Centre for Research and Advanced Studies

196 of the National Polytechnic Institute from eggs kindly donated by Centre for Research Dr.

197 Hideyo Noguchi. The mosquito larvae mortalities were monitored every 4 hours until 48 hours

198 post-exposure (time allowed before the transformation of larvae into pupae). Dead mosquito

199 larvae (those without movement when touched with a fine painting brush) were washed (three

200 times) with distilled water and fixed in DNA/RNA Shield.

Peer] reviewing PDF | (2021:03:58801:1:1:NEW 13 May 2021) 
201 The survival of Ae. aegypti larvae was estimated through a survival analysis (Kaplan-Meier

202 Estimate). This analysis is a nonparametric statistical method to estimate the probability of the

203 mosquito larvae survival after infection with $H$. indica through time. To determine the dosage at

204 which $H$. indica caused 50\% of mortality in Ae. aegypti larvae, a probit analysis was conducted

205 following Finney (1971) procedure. The software used for survival and probit analysis was

206 MedCalc ${ }^{\circledR}$ (MedCalc Software Ltd, Ostend, Belgium).

\subsection{Bacterial detection by $16 \mathrm{~S}$ rRNA sequencing}

In order to get a broad comparison of the bacterial composition from infected and non-infected Ae. aegypti larvae, genomic DNA was extracted from a pool of three larvae for each type of

211 samples (infected and non-infected) with the DNAeasy blood and tissue extraction kit (Qiagen,

212 Valencia, CA, USA). DNA quality was verified by agarose gel (1\%) electrophoresis. PCR

213 Amplification of hypervariable V3 and V4 regions of 16S rRNA, library preparation and

214 Illumina sequencing were performed as previously described in Valencia-Agami et al. (2019).

215 Bioinformatic processing were done with the QIIME2 (2019) pipeline (Caporaso et al., 2010).

216 The error correction, denoising and ASVs taxonomical assignation were performed as previously

217 reported in Cadena et al. (2019).

\section{RESULTS}

From the 12 collection sites in the Yucatán state, four sites were positive for EPNs (Cansahcab,

221 Sucila, Ticuch and Dzan). From the 144 soil samples, six isolates were positive for 
222 Heterorhabditidae (4.16\%). Most of the nematodes were isolated from Dzan, Yucatán. Based on

223 the nucleotide sequence analysis of $28 \mathrm{~S}$ and ITS, we concluded that four isolates belonged to the

224 species Heterorhabditis indica and two isolates were identified as Heterorhabditis n. sp.

\subsection{Molecular identification and phylogenetic analysis of Heterorhabditis}

227

228

229

230

231

232

233

234

235

236

237

238

239

240

241

242

243

The comparison of nucleotide sequences with the sequences published in GenBank through BLAST allowed us to molecularly identify our EPN from Yucatán state, where some of our specimens had a high percentage of similarity with $H$. indica $(99.73-100 \%$ in ITS and 99.89$100 \%$ in $28 \mathrm{~S}$ ). With respect to the phylogenetic analysis, the final ITS data set consisted of 57 sequences representing 17 species, and the alignment had a length of $1092 \mathrm{bp}$. The substitution model selected for this data set was GTR $+\mathrm{I}$. Nucleotide frequencies were $\mathrm{A}=0.254, \mathrm{C}=0.203, \mathrm{G}=$ 0.255 and $\mathrm{T}=0.288$. The ML value of the tree was $-\ln =4451.710121$. The phylogenetic tree obtained with the ITS data set showed that the new sequences of this study were grouped into two clades, one corresponding to $H$. indica and another one that belongs to an unidentified species: Heterorhabditis n. sp. (Fig. 2). In Dzan, Yucatán the two species H. indica and Heterorhabditis n. sp. were present, while only Heterorhabditis n. sp. was found in Tikuch. In the phylogenetic tree, Heterorhabditis $\mathrm{n}$. sp. was phylogenetically closest to the clade formed by Heterorhabditis taysearae + Heterorhabditis mexicana (Fig. 2), with an interspecific genetic distance of $1.31 \%$ (10 nucleotides) with both species and there was no intraspecific variation between the specimens of Heterorhabditis $\mathrm{n}$. sp. All sequences identified as $H$. indica were grouped with other sequenced $H$. indica specimens, in a clade that also contained to $H$. noenieputensis (Fig. 2). The genetic distance between $H$. indica and H. noenieputensis was 1 to 
$2441.2 \%$ ( 7 to 9 nucleotides). The intraspecific genetic distance of $H$. indica was from 0 up to $0.4 \%$.

245 For the $28 \mathrm{~S}$ gene, the data set consisted of 45 sequences representing 16 species, with a length of

246934 bp. The substitution model selected was $G T R+G+I$. Nucleotide frequencies were $A=0.260$,

$247 \mathrm{C}=0.193, \mathrm{G}=0.295$ and $\mathrm{T}=0.252$. The $\mathrm{ML}$ value of the tree was $-\ln =2146.711150$. The

248 phylogenetic relationships of both Heterorhabditis species with the 28S gene were practically the

249 same as those obtained with the ITS. As in ITS, the specimens sequenced in this study were

250 grouped into two independent clades. The nematodes from Tikuch were separated as

251 Heterorhabditis n. sp. and the genetic distance between the Heterorhabditis n. sp. and $H$.

252 mexicana specimens was 0.5 to $0.7 \%$ (4 to 6 nucleotides) with no intraspecific differences

253 between the Heterorhabditis n. sp. On the other hand, the nematodes from Cansahcab, Dzan and

254 Sucila were grouped as $H$. indica, with an interspecific genetic distance of $0.3 \%$ ( 3 nucleotides)

255 with $H$. noenieputensis. The intraspecific genetic distance of the $H$. indica was up to $0.2 \%$ (2 256 nucleotides).

\subsection{Soil analysis}

H. indica and Heterorhabditis $\mathrm{n}$. sp. were found in soils used for agriculture and cattle farming.

The characteristics of the soil of the localities where these EPN were and were not found are

261 presented in Table 1. Apparently, the relevant characteristics for the presence of these EPN in

262 soil were chemical variables such as potassium and calcium (See table 2). Significant differences

263 in variables such as $\mathrm{P}(\mathrm{mg} / \mathrm{kg}), \% \mathrm{OM}$ and soil type were not found between EPN positive and

264 EPN negative samples $(P>0.05)$. 


\subsection{Experimental infection}

267 The percentage of survival values of Ae. aegypti mosquito larvae exposed to $H$. indica are shown

268 in Figure 3. The mean survival values of the mosquito larvae exposed to $H$. indica and their $95 \%$

269 confidence intervals are shown in Table 3. There was a significant difference in survival when

270 comparing the average mortality of Ae. aegypti larvae between the various nematode

271 concentrations and the control (Kaplan-Meier estimate, P-value $=0.0279$ ). Figure 3 showed that

272 the highest mortality (80\%) in Ae. aegypti larvae was achieved using 1:2,520 1/IJs and 1:3780

273 1/IJs after 46 hours. The lowest mortality obtained was at $24 \%$ for the concentration with the

274 highest number of nematodes (1:5,040 1/IJ). The lethal dose (LD50) was estimated at different

275 exposure times (Table 4). The LD50 of $\mathrm{H}$. indica at $24 \mathrm{hr}$ was of 7,040 infective juveniles, with a 276 confidence interval of $95 \%$ from 5,802 to 8,277 infective juveniles.

\subsection{Bacterial composition of Ae. aegypti larvae}

279

280

281

282

283

284

285

286
Bioinformatic analyses of the $16 \mathrm{~S}$ rRNA sequences indicated that the pool of mosquito larvae infected by $H$. indica was composed by twenty ASVs corresponding to 9 families and 12 genera (Fig. 4). In which, at a lower taxonomic level, Photorhabdus was the dominant genus in the sample (74.2\%). However, Elizabethkingia (10.4\%), Pseudomonas (4.1\%), Delftia (2.7\%), Achromobacter (1.9\%) Phreatobacter (1.6\%) and other less abundant $(<1 \%)$ genera were also detected (Fig. 4). In contrast, the pool of non- infected mosquito larvae (control), exhibited 19 ASVs from 13 families and 14 genera (Fig. 4). Delftia (22.61\%), Chryseobacterium (18.19\%), Brevundimonas (15.06\%) and Flavobacterium (11.34\%) were the most abundant genera (Fig. 4).

Peer] reviewing PDF | (2021:03:58801:1:1:NEW 13 May 2021) 


\section{Discussion}

Heterorhabditis indica and Heterorhabditis n. sp., are reported for the first time in Yucatán state, México. The finding of these nematode species were corroborated by the ITS and 28S genes.

291 Our original hypothesis that $H$. indica would be able to produce a high percentage of mortality ( $>$ $29270 \%$ ) in Ae. aegypti mosquito larvae was supported. This was confirmed since $H$. indica, in 293 association with its bacterial composition, was able to induce $80 \%$ mortality in Ae. aegypti larvae 294 at the concentration of 2,520 IJs/I by 48 hrs post-infection. This is the first record of EPN present

295 in Yucatán state soil, and the results obtained were promising in terms of the pathogenicity of 296 this nematode and its potential as a biological control alternative.

\subsection{Molecular identification and phylogenetic analysis of $\boldsymbol{H}$. indica and Heterorhabditis $\mathbf{n}$.} sp.

300 The analysis of the nucleotide sequences and phylogenetic analysis of the 28S and ITS of the 301 isolated nematodes of Dzan, Cansahcab and Sucila in this study allowed us to corroborate the

302 taxonomic identification of two species of Heterorhabditis. In the case of Heterorhabditis n. sp.,

303 the phylogenetic analysis and genetic distances indicated that this nematode is a genetically

304 different species from those sequenced and previously described. The finding of $H$. indica in

305 Yucatán state is not surprising since apparently is a species distributed worldwide (e.g. Saleh et

306 al., 2001; Dolinski et al, 2008; Bruno et al, 2020). Phylogenetic analysis positioned H. indica

307 from Yucatán state within the Indica group, named by Andaló, Nguyen \& Moino, 2006 (Nguyen, 
308 Shapiro-Ilan \& Mbata, 2008; Malan et al., 2014; Dhakal et al. 2020). All species of the Indica-

309 group are found in the tropics and subtropics zones and this group is divided into two subclades:

310 the Indica-subclade conformed of H. indica and H. noenieputensis, and the Baujardi-subclade

311 with H. baujardi, H. amazonensis, H. floridensis, H. mexicana and H. taysearae (Dhakal et al.,

312 2020). Particularly, the two EPN species of our study were phylogenetically associated with

313 each of the previously described subclades. Heterorhabditis n. sp. from Dzan and Tikuch was

314 grouped in the Baujardi-subclade, and there were no intraspecific differences between the

315 specimens sequenced with both markers. The phylogenetic position of Heterorhabditis n. sp.

316 makes sense geographically, because it was grouped with species that have been described in

317 North America, such as H. mexicana and H. floridensis (Nguyen et al., 2004; Nguyen, Mrek \&

318 Webster, 2006).

319 Our study reports for the first time, the presence of Heterorhabditis n. sp. in the Yucatán state. It

320 should also be noted that the sequences of the undescribed species are grouped with two

321 sequences that were identified as H. mexicana in the GenBank; however, the phylogenetic

322 analysis showed that this sequence does not correspond to the species described by Nguyen et al. 323 (2004).

\subsection{Soil samples}

326 The soil type (sand, silt, clay) did not seem to be as important as the physico-chemical

327 composition of soil for the presence of EPN. The nematodes were present in soil with alkaline

$328 \mathrm{pH}$ going from 7.2 to 8 . It has been proved that the alkaline levels (10) or acid levels (5.6) reduce

329 survival of EPN, in comparison to values closer to neutrality (Plante et al., 2006). This result 
330 coincides with those reported by Rodriguez et al. (2009) where it was observed that

331 Heterorhabditis is present in soils with an alkaline $\mathrm{pH}$ compared to Steinernema.

332 The potassium concentration reported in soil samples in this study was 0.03 to $14.7(\mathrm{Cmol}(+) / \mathrm{kg})$

333 and 17 to $80.2(\mathrm{Cmol}(+) / \mathrm{kg})$ of calcium. Alumai et al. (2006) mentioned not finding an

334 individual correlation between the presence of EPN and factors such as calcium, potassium and

$335 \mathrm{pH}$ in turfgrass, but together contribute to the cation exchange capacity of the soil. Thus,

336 apparently $\mathrm{K}$ and $\mathrm{Ca}$ could be the factors that influenced in the presence and distribution of these

337 EPNs in Yucatán State soil.

338 Despite of the fact that significant differences were not found between soil types, EPN were

339 found in soils where agriculture and stockbreeding are carried out and were classified as sandy-

340 clay soils. In addition, Dolinski et al. (2008) suggest that $H$. indica, together with other EPN

341 typical of tropical regions, can be found in environments with a relative high percentage of sand.

342 Yooyangket et al. (2018) reported 13 isolates of Heterorhabditis and 14 isolates of the

343 Steinernema in clay soils of the Nam Nao National Park, Thailand. Therefore, the difference

344 between the Yucatán and Thai soils would be in the sand contents. Whether or not this sand

345 content is acting as a limiting factor for the survival of the Yucatán EPN should be tested

346 experimentally. In the same way, it is important to extend this research to new sampling points in

347 the Yucatán State probably without the influence of agriculture and stockbreeding to determine

348 whether the poor EPN species richness detected is a regional pattern. This is important because

349 other authors have noted that edaphic factors may dramatically influence the presence of EPN

350 (Lacey \& Kaya, 2000). 


\section{4.3. Experimental infection}

353 Our results demonstrated that Ae. aegypti larvae were susceptible to H. indica (and their bacteria)

354 recovered from Yucatán state at 2,520 nematodes per mosquito larvae (Fig. 3). It was expected

355 that a higher number of nematodes would produce higher mortality. However, the 5,040:1

356 concentration reached only $25 \%$ mortality in mosquito larvae. A possible explanation for the

357 poor performance of high concentrations of nematodes in producing mosquito larvae mortality is

358 that of intraspecific competition by nutrients and space, which in turn reduced their infectivity

359 and survival when of the nematode concentration increases. This is a process has been observed

360 previously by Sen-Selvan, Campbell \& Gaugler (1993), who compared the effect of increasing $S$.

361 carpocapsae and H. bacteriophora in G. mellonella larvae. The authors reported that when the

362 number of nematodes per host increased, the percentage of penetration decreased. Certainly, our

363 results suggest that the use of nematode concentrations as high as 5,040 $\mathrm{IJ} / \mathrm{I}$ is not effective nor

364 economically feasible. However, now that the most effective nematode concentration to produce

365 mosquito larvae mortality has been established $(2,520 \mathrm{IJS} / \mathrm{I})$, the following task will be to

366 decrease the number of IJs mantaining the same mortality level.

367 In terms of mosquito larvae mortality, Peschiutta, Cagnolo \& Almirón, (2014) reported the

368 susceptibility of $A$ e. aegypti to $H$. bacteriophora, obtaining $84 \%$ mortality at a concentration of

369750 IJs per mosquito larvae. Our results contrast with those reported in H. bacteriophora, since a

370 lower concentration of nematodes was enough to obtain high mortality in Ae. aegypti. We

371 consider the results obtained here as promising since the Yucatán State strain of $H$. indica

372 produced a high mortality level in normal tropical environmental conditions with regards to

373 temperature $\left(>29.6^{\circ} \mathrm{C} ;>85.3^{\circ} \mathrm{F}\right), \mathrm{CaCo}_{3}(408 \mathrm{ppm})$ and $\mathrm{pH}(6.88)$ compared to those of

374 Peschiutta, Cagnolo \& Almirón, (2014) developed in laboratory conditions at $26^{\circ} \mathrm{C}$. However, 
375 the percentage mortality reached with $H$. indica from Yucatán state was higher than that obtained

376 by Pandii et al. (2008) who tested the infective capacity of $S$. carpocapsae and H. indica (Local

377 Thai strain) in Culex gelidus, obtaining a mortality of $63 \%$ and $13 \%$, respectively, at a

378 concentration of 4,000 IJs per mosquito larvae. Clearly, additional bioassays exposing $\mathrm{Ae}$.

379 aegypti larvae to lower concentrations of $H$. indica from Yucatán state are necessary. Although

380 in this work we did not evaluate the physiological responses of mosquito larvae to $H$. indica

381 infection, it is known that EPN can cause mortality by suppressing the immune response of

382 insects by reducing the number of haemocytes and phenoloxidase levels (Lalitha et al., 2018).

384 4.4. Differences in the bacterial composition of infected and non - infected Ae. aegypti 385 larvae

386 16S rRNA sequences allowed a broad comparison of the bacterial composition of infected and

387 non - infected Ae. aegypti larvae. Several differences were observed in the two type of samples.

388 However, the main difference was that Photorhabdus was the dominant genus in the infected 389 mosquito larvae, representing $74.2 \%$ of the total microbial composition. Thus, we suggest that

390 the endosymbiotic Photorhabdus most likely transported by H. indica, was able to infect Ae.

391 aegypti larvae; something that did not happen in the non - infected mosquito larvae. Moreover,

392 Elizabethkingia was also found as part of the microbial community of Ae. aegypti larvae infected

393 by EPN. Boissière et al (2012) reported Elizabethkingia spp. in 68\% Anopheles gambiae

394 mosquito collected in Cameroon. It is very likely that some species of Elizabethkingia are

395 symbionts of mosquitoes, since they have been found through the life cycle of Ae. aegypti (Coon 396 et al., 2014). 
397 Only four genera were shared between the control and infected mosquito larvae: Acinetobacter,

398 Flavobacterium, Delftia and Pseudomonas. Jimenez et al. (2016) reported species of

399 Pseudomonas and Delftia, which are part of the EPN microbiota in species such as Rhabditis

400 regina, with the capacity of causing mortality in Phyllophaga sp., Anomalla sp. and G.

401 mellonella. Another bacterial genus found in the microbiota of mosquito larvae infected by $H$.

402 indica was Achromobacter which, despite presenting a relative low abundance (1.9\%),

403 apparently could be also pathogenic to insects. For example, Poinar and Thomas (1966) isolated

404 Achromobacter nematophilus from the nematode Neoplectana sp. while demonstrating its

405 pathogenicity in Galleria mellonella larvae.

406 By high throughput sequencing, it was possible identify bacterial genera with low relative

407 abundance $(<1.2 \%)$ such as Flavobacter, Stenotrophomonas, Acinetobacter, Lysinibacillus,

408 Taibaiella and Paenibacillus. Some of these bacteria have been reported to have low

409 pathogenicity to mosquito larvae, especially those of the genera Lysinibacillus and Paenibacillus

410 (Rojas-Pinzón \& Dussán, 2017). Cambon et al. (2020) mentioned that the host's 'normal'

411 microbiota may be present in the host without causing damage, but under specific stress

412 conditions such as infection with EPN, these opportunistic bacteria could manifest if the host

413 immune system is suppressed. In the current study, the role these bacteria play during the

414 infection process of the mosquito larvae or their interaction with the immune capacity of these

415 larvae is unknown. For this reason, it would be pertinent to perform experiments concerning the

416 infections by $H$. indica bacterial symbionts and other bacteria considered as entomopathogenic,

417 to formulate bacterial associations with greater pathogenic capacity. This is an interesting

418 research avenue since it could provide us with new nematode-bacteria consortia acting on real

419 environmental conditions against mosquito larvae. 
420 In summary, our results suggest that the local strain of $H$. indica in association with their

421 endosymbiotic bacteria have the infective capacity to induce $80 \%$ mortality in Ae. aegypti larvae.

422 The high mortality of Ae. aegypti larvae apparently was related to bacteria of the genus

423 Photorhabdus, since this was the numerically dominant endosymbiont compared to other non-

424 symbiotic bacteria reported in this work. However, changes in the structure of the microbial

425 community of Ae. aegypti larvae were observed as a result of exposure with $H$. indica. Even

426 when EPN and/or their symbiotic bacterial associations appear as very promising biocontrol

427 tools to kill mosquito larvae, it is important to be very careful about the release of these

428 organisms into the environment, even if they are native. This is especially important for a region

429 such as Yucatán state where native (and introduced) bees are important insects related to the

430 pollination of wild plants, and beekeeping is an important economic activity in the countryside.

431 Therefore, further studies should be performed to determine the susceptibility of beneficial

432 insects such as European bees and stingless bees such as Meliponas to EPN and the toxins

433 released by their symbiotic bacteria.

435 Conflict of Interest

436 The authors declare that there is no conflict of interest.

\section{Author Contributions}

- M.B.A.L, V.M.V.M conceived research.

441 - M.B.A.L, conducted experiments.

- M.B.A.L, H.E.M., J.Q.G.M. contributed material. 
443

444

445

446

447

448

449

450

451

452

453

454

455

456

457

458

459

460

461

462

463

- H.E.M. Soil sample analysis

- M.B.A.L, J.Q.G.M., D.H.M., D.C.G. analyzed data and conducted statistical analyses.

- M.B.A.L, V.M.V.M, J.Q.G.M., D.H.M wrote the manuscript.

- $\quad$ V.M.V.M. secured funding.

- All authors read and approved the manuscript.

\section{Data Availability Statement}

When accepted, the data that support the findings of this study will be openly available at https://zenodo.org/badge/DOI/10.5281/zenodo.4618576.svg

\section{Funding}

M.B.A.L benefited from a PhD student grant from the Consejo Nacional de Ciencia y Tecnología (CONACYT) of the Mexican Government (Scholarship No. 340012).

\section{Acknowledgements}

The authors would like to thank to Dr. Jorge Eugenio Ibarra Rendón and Andrés Martínez Aquino by their assistance in the molecular identification, MSc José Sandoval and Biologist José Germán López Guerra for their help in field work, and the staff of the Aquatic Pathology Laboratory at CINVESTAV-Mérida for their help in laboratory work.

\section{References}


464 Akhurst, R.J., 1993. Bacterial symbionts of entomopathogenic nematodes the power behind the 465 throne, In: Bedding, R., Akhurst, R., Kaya, H. (Eds.), Nematodes and the Biological control of 466 Insect Pests. CSIRO Publications East, Melboune, Australia, pp. 127-135.

Altschul, S., Gish, W., Miller, W., Myers, E., Lipman, D., 1990. Basic Local Aligment Search 469 Tool. J. Mol. Biol. 215, 403-10. https://doi.org/10.1016/S0022-2836(05)80360-2.

Alumai, A., Grewal, P.S., Hoy, C.W., Willoughby, D.A., 2006. Factors affecting the natural 472 occurrence of entomopathogenic nematodes in turfgrass. Biol. Control. 36, 368-374. https://doi.org/10.1016/j.biocontrol.2005.08.008.

Andaló, V., Nguyen, K., Moino A., 2006. Heterorhabditis amazonensis n. sp. (Rhabditida:

476 Heterorhabditidae) from Amazonas, Brazil. Nematol. 8, 853-867.

477 https://doi.org/10.1163/156854106779799286.

479 Babic, I., Fischer-Le S.M., Giraud, E., Boemare, N., 2000. Occurrence of natural dixenic 480 associations between the symbiont Photorhabdus luminescens and bacteria related to 481 Ochrobactrum spp. in tropical entomopathogenic Heterorhabditis spp. (Nematoda, Rhabditida). 482 Microbiol. 146, 709-18. https://doi.org/10.1099/00221287-146-3-709. 
483

484 Bedding, R.A., Akhurst, R.J., 1975. A simple technique for the detection of insect parasitic

485 rhabditid nematodes in soil. Nematol. 21 (1),109-110.

486 https://doi.org/10.1163/187529275X00419.

487

488

Bedding, R.A., Akhurst, R.J., Kaya, H.K., 1993. Future prospects of entomogenous and

489 entomopathogenic nematodes, In: Bedding, R., Akhurst, R. J., Kaya, H. K. (Eds.), Nematodes

490 and the Biological Control of Insect Pests. East Melbourne, pp. 157-170.

491 http://hdl.handle.net/102.100.100/244689?index $=1$.

492 Bode, H., 2009. Entomopathogenic bacteria as a source of secondary metabolites. Curr. Opin.

493 Chem. Biol. 13, 224-30. https://doi.org/10.1016/j.cbpa.2009.02.037.

Boissière, A., Tchioffo, M.T., Bachar. D., Abate, L., Marie, A., Nsango, S.E., Shahbazkia, H.R., 496 Awono-Ambene, P.H., Levashina, E.A., Christen, R., Morlais, I., 2012. Midgut microbiota of the malaria mosquito vector Anopheles gambiae and interactions with Plasmodium falciparum infection. PLoS Pathog. 8, e1002742. https://doi.org/10.1371/journal.ppat.1002742.

Blair, A., Ritz, B., Wesseling, C., Freeman, L., 2014. Pesticides and human health. Occup.

500 Environ. Med. 72 (2). https://doi.org/10.1136/oemed-2014-102454. 
502 Bruno, P., Machado, R.A.R., Glauser, G., Köhler, A., Campos- Herrera, R., Bernal, J., Toepfer,

503 S., Erb, M., Robert, C.A.M., Arce, C.C.M., Turlings, T.C.J., 2020. Entomopathogenic nematodes

504 from Mexico that can overcome the resistance mechanisms of the western corn rootworm. Sci.

505 Rep. 10 (1). https://doi.org/10.1038/s41598-020-64945-x.

506

507 Cadena, S., Aguirre-Macedo, M.L., Cerqueda-García, D., Cervantes, F.J., Herrera-Silveira, J.A., 508 García-Maldonado, J.Q., 2019. Community structure and distribution of benthic Bacteria and 509 Archaea in a stratified coastal lagoon in the Southern Gulf of Mexico. Estuarine, Coastal and

510 Shelf Science, 230, 106433. doi:10.1016/j.ecss.2019.106433.

511

512 Cambon, M.C., Lafont, P., Frayssinet, M., Lanois, A., Ogier, J.C., Pagès, S., Parthuisot, N., 513 Ferdy, J.B., Gaudriault, S., 2020. Bacterial community profile after the lethal infection of

514 Steinernema-Xenorhabdus pairs into soil-reared Tenebrio molitor larvae. FEMS Microbiol. Ecol.

515 96. https://doi.org/10.1093/femsec/fiaa009.

516

517 Caporaso, J.G., Kuczynski, J., Stombaugh, J., Bittinger, K., Bushman, F.D., Costello, E.K., 518 Fierer, N., Peña, A.G., Goodrich, J.K., Gordon, J.I., a Huttley, G., Kelley, S.T., Knights, D., 519 Koenig, J.E., Ley, R.E., a Lozupone, C., Mcdonald, D., Muegge, B.D., Pirrung, M., Reeder, J., 520 Sevinsky, J.R., Turnbaugh, P.J., a Walters, W., Widmann, J., Yatsunenko, T., Zaneveld, J., 521 Knight, R., 2010. QIIME allows analysis of highthroughput community sequencing data. Nature 522 7, 335-336. https://doi.org/ 10.1038/nmeth.f.303. 
524 Chitra, P., Sujatha, K., Alagarmalai, J., 2017. Entomopathogenic nematode as a biocontrol agent

525 - Recent trends - A Review. Int. J. Adv. Res. Biol. Sci. 4, 9-20.

526 https://doi.org/10.22192/ijarbs.2017.04.01.002.

528 Coon, K.L., Vogel, K.J., Brown, M.R., Strand, M.R., 2014. Mosquitoes rely on their gut

529 microbiota for development. Mol. Ecol. 23, 2727-2739. https://doi.org/10.1111/mec.12771.

530

531 Darriba, D., Taboada, G.L., Doallo, R., Posada, D., 2012. jModelTest 2: More models, new

532 heuristics and parallel computing. Nat. Methods. 9, 772. https://doi.org/10.1038/nmeth.2109.

534 Dhakal, M., Nguyen, K.B., Hunt, D.J., Ehlers, R., Spiridonov, S.E., Subbotin, S.A., 2020.

535 Molecular identification, phylogeny and phylogeography of the entomopathogenic nematodes of

536 the genus Heterorhabditis Poinar, 1976: a multigene approach, Nematol. 1-17.

537 https://doi.org/10.1163/15685411-bja10052.

538

539 Dilipkumar, A., Karthik, R.R., Chinnaperumal, K., Balasubramani, G., Paramasivam, D., Arul,

540 D., Pachiappan, P., 2019. Isolation and growth inhibition potential of entomopathogenic

541 nematodes against three public health important mosquito vectors. Exp. Parasitol. 197, 76-84.

542 https://doi.org/10.1016/j.exppara.2018.11.001.

544 Dolinski, C., Kamitani, F.L., Machado, I.R., Winter, C.E., 2008. Molecular and morphological

545 characterization of heterorhabditid entomopathogenic nematodes from the tropical rainforest in 
546 Brazil. Mem. Inst. Oswaldo Cruz. 103 (2), 150-159. https://doi.org/10.1590/S0074-

54702762008000200005.

548

549 Eivazian, K.N., Mohammadi, D., Girling, R., 2017. New reports on dixenic associations between

550 the symbionts of entomopathogenic nematodes, Photorhabdus and Xenorhabdus, and non-

551 symbiotic bacteria. J. Crop Prot. 6 (4), 497-511.

552

553 Engel, P., Moran, N., 2013. The gut microbiota of insects - diversity in structure and function.

554 FEMS Microbiol. Rev. 37, 699-735. https://doi.org/10.1111/1574-6976.12025.

555 Finney, D.J., 1971. Probit Analysis, third Ed. Cambridge University Press, London.

556

557 García-Varela, M., Nadler, S.A., 2005. Phylogenetic relationships of Palaeacanthocephala

558 (Acanthocephala) inferred from SSU and LSU rDNA gene sequences. J. Parasitol. 91, 1401-

559 1409. https://doi.org/10.1645/GE-523R.1.

560 Gee, G.W., Bauder, J.W., 1986. Particle-size analysis, In: Klute A. (Eds.) Methods of soil

561 analysis. Part 1. 2nd ed. Agron. Monogr. 9. ASA and SSSA. Madison, WI, pp. 383-411.

562

563 Girón, P.S., Ruiz, V.J., Pérez, P.R., Sánchez, G.J.A., Aquino, B.T., 2012. Isolation of

564 entomopathogenic nematodes and control of Phyllophaga vetula Horn in Oaxaca, México. Afr. J.

565 Biotechnol. 11, 16525-16531. https://doi.org/10.5897/AJB12.448. 
567 Gouge, D.H., Snyder, J.L., 2006. Temporal association of entomopathogenic nematodes

568 (Rhabditida: Steinernematidae and Heterorhabditidae) and bacteria. J. Invertebr. Pathol. 91, 147-

569 157. https://doi.org/10.1016/j.jip.2005.12.003.

570

571 Jackson, T., Wang, H., Nugent, M.J., Griffin, C.T., Burnell, A.M., Dowds, B.C.A., 1995.

572 Isolation of insect pathogenic bacteria, Providencia retfgeri, from Heterorhabditis spp. J. Appl.

573 Bacteriol. 78, 237-244. https://doi.org/10.1111/j.1365-2672.1995.tb05022.x.

574

575 Jiménez, C.J.G., Canales, L.J., Lara, R.N., Rosenblueth, M., Martínez, R.E., Contreras, G.J., 576 2016. Microbiota from Rhabditis regina may alter nematode entomopathogenicity. Parasitol.

577 Res. 115, 4153-4165. https://doi.org/10.1007/s00436-016-5190-3.

578

579 Kaya, H.K., Stock, S.P., 1997. Techniques in insect nematology, In: Lacey L. A. (Eds.), Manual

580 of techniques in insect pathology. Academic Press, London, pp. 281-324.

581 https://doi.org/10.1016/B978-012432555-5/50016-6.

582

583 Kovendan, K., Chandramohan, B., Govindarajan, M., Jebanesan, A., Kamalakannan, S., Vincent,

584 S., Benelli, G., 2018. Orchids as sources of novel nanoinsecticides? Efficacy of Bacillus

585 sphaericus and Zeuxine gracilis-fabricated silver nanoparticles against dengue, malaria and 
586 filariasis mosquito vectors. J. Clust. Sci. 29, 345-357. https://doi.org/10.1007/s10876-018-13315874.

588

589 Kuo, S., 1996. Phosphorus, In: Sparks D.L. (Eds.), Methods of Soil Analysis Part 3: Chemical

590 Methods. SSSA Book Series 5, Soil Science Society of America, Madison, Wisconsin, pp. 869591920.

592

593

Lacey, L.A., Kaya, H.K., 2000. Field Manual of Techniques in Invertebrate Pathology. J.

594 Invertebr. Pathol. 84, 15-23. https://doi.org/10.1007/978-94-017-1547-8.

595

596 Lalitha, K., Karthi, S., Vengateswari, G., Karthikraja, R., Perumal, P., Shivakumar, M. S.,

597 2018. Effect of entomopathogenic nematode of Heterorhabditis indica infection on immune and 598 antioxidant system in lepidopteran pest Spodoptera litura (Lepidoptera: Noctuidae). Journal of 599 Parasit Dis. 42, 204 211. https://doi.org/10.1007/s12639-018-0983-1.

600

601 Malan, A.P., Knoetze, R., Tiedt, L., 2014. Heterorhabditis noenieputensis n. sp. (Rhabditida:

602 Heterorhabditidae), a new entomopathogenic nematode from South Africa. J. Helminthol. 88, 603 139-51. https://doi.org/10.1017/S0022149X12000806. 
605 Nadler, S.A., Hudspeth, D.S.S., 1998. Ribosomal DNA and phylogeny of the Ascaridoidea 606 (Nemata: Secernentea): Implications for morphological evolution and classification. Mol.

607 Phylogenetics Evol. 10, 221-236. https://doi.org/10.1006/mpev.1998.0514.

608 Nelson, D.W., Sommers, L.E., 1996. Total carbon, organic carbon, and organic matter, In:

609 Sparks D.L. (Eds.), Methods of Soil Analysis: Part 3. Chemical Methods, Agronomy

610 Monograph. American Society of Agronomy-Soil Science Society of America, Madison,

611 Wisconsin, pp. 961-1010. https://doi.org/10.2136/sssabookser5.3.c34.

612

613 Nguyen, N.C., Shapiro, I., Stuart, D.L., McCoy, R.J., James, R.R., Adams, B.J., 2004.

614 Heterorhabditis mexicana n. sp. (Rhabditida: Heterorhabditidae) from Tamaulipas, Mexico and 615 morphological studies of the bursa of Heterorhabditis spp. Nematol. 6, 231-244.

616 https://doi.org/10.1163/1568541041218031.

617

618 Nguyen, K.B., Mrek, Z.K., Webster, J.M., 2006. Morphological and molecular characterization 619 of a new isolate of Steinernema feltiae (Filipjev, 1934) from Vancouver, Canada, with 620 morphometrical comparison with the topotype population from Russia. Zootaxa. 1132, 51-619. 621 https://doi.org/10.11646/zootaxa.1132.1.3.

622

623 Nguyen, K.B., Shapiro, I.D., Mbata, G.N., 2008. Heterorhabditis georgiana n. sp. (Rhabditida:

624 Heterorhabditidae) from Georgia, USA. Nematol. 10, 433-448.

625 https://doi.org/10.1163/156854108783900276.

626 
627 Nthenga, I., Knoetze, R., Berry, S., Tiedt, L.R., Malan, A.P., 2014. Steinernema sacchari n. sp.

628 (Rhabditida: Steinernematidae), a new entomopathogenic nematode from South Africa. Nematol.

629 16, 475-494. https://doi.org/10.1163/15685411- 00002780.

630

631 Olvera, A., Benoit, P., Barriuso, E., Ortiz, L., 2008. Sorption and desorption of organophosphate

632 pesticides, parathion and cadusafos, on tropical agricultural soils. Agron. Sustain. Dev. 28, 231633 238. https://doi.org/10.1051/agro:2008009.

634

635 Pandii W., Maharmart, S., Boonchuen, S., Silapanuntakul, S., Somsook, V., 2008. Efficacy of 636 entomopathogenic nematodes (Nematoda: Rhabditida) against Culex gelidus (Diptera:

637 Culicidae) larvae. Journal Vector Borne Dis. 5, 24-35.

638

639 Patrick Jr. W.H., Gambrell, R.P., Faulkner, S.P., 1996. REDOX measurements of soils, In:

640 Sparks D.L. (Eds.), Methods of Soil Analysis: Part 3. Chemical Methods, Agronomy

641 Monograph. American Society of Agronomy-Soil Science Society of America, Madison,

642 Wisconsin, (pp. 1085-1123). https://doi.org/10.2136/sssabookser5.3.c42.

643 Peschiutta, M.L., Cagnolo, S.R., Almirón, W.R., 2014. Susceptibility of larvae of Aedes aegypti

644 (Linnaeus) (Diptera: Culicidae) to entomopathogenic nematode Heterorhabditis bacteriophora

645 (Poinar) (Rhabditida: Heterorhabditidae). Rev. Soc. Entomol. Argent. 73, 99-108.

646 
647 Peters, A., 1994. Susceptibility of Leatherjackets (Tipula paludosa and Tipula oleracea;

648 Tipulidae; Nematocera) to the Entomopathogenic Nematode Steinernema feltiae. J. Invertebr

649 Pathol. 63, 163-171. https://doi.org/10.1006/jipa.1994.1031.

650

651 Peters, A., Ehlers, R., 1997. Encapsulation of the entomopathogenic nematode Steinernema

652 feltiae in Tipula oleracea. J. Invertebr. Pathol. 69, 218-222.

653 https://doi.org/10.1006/jipa.1996.4648.

654

655 Plante, A.F., Conant, R.T., Stewart, C.E., Paustian, K., Six, J., 2006. Impact of soil texture on the

656 distribution of soil organic matter in physical and chemical fractions. Soil Sci. Soc. Am. J. 70,

657 287-296. https://doi.org/10.2136/sssaj2004.0363.

658 Poinar Jr., G.O., Thomas, G.M., 1966. Significance of Achromobacter nematophilus Poinar and

659 Thomas (Achromobacteraceae:Eubacteriales) in the development of the nematode, DD-136

660 (Neoaplectana sp., Steinernematidae). Parasitology, 56, 385-390.

661 https://doi.org/10.1017/s0031182000070980.

662

663 Polanco, R.A.G., Navarro, A.J.N., Solorio S.J., Mena, R.G.J., Marrufo, G.J.M., Del Valls

664 Casillas, T.A., 2015. Contamination by organochlorine pesticides in the aquifer of the Ring of

665 Cenotes in Yucatán, México. Water Environ J. 29, 140-150.

666 https://doi.org/10.1111/wej.12080.

667 
668 Rambaut, A., 2016. FigTree v1.4.3. Molecular Evolution, Phylogenetics and Epidemiology.

669 http://tree.bio.ed.ac.uk/software/figtree/ (accessed 7 January 2021).

670

671 Rhoades, J.D., 1996. Salinity: electrical conductivity and total dissolved solids, In: Sparks D.L.

672 (Eds.), Methods of Soil Analysis: Part 3. Chemical Methods, Agronomy Monograph. American

673 Society of Agronomy-Soil Science Society of America, Madison, Wisconsin, pp. 417-436.

674 https://doi.org/10.2136/sssabookser5.3.c14.

675

676 Rodríguez, D., Torres, M., Uribe, L., Flores, L., 2009. Susceptibilidad de los estadios L2 y L3 de

677 Phyllophaga elenans a una cepa nativa de Heterorhabditis sp. en condiciones de invernadero.

678 Agron. Costarricense. 33, 171-182.

679 Rojas-Pinzón, P.A., Dussán, J., 2017. Efficacy of the vegetative cells of Lysinibacillus

680 sphaericus for biological control of insecticide-resistant Aedes aegypti. Parasites Vectors. 10,

681 231. https://doi.org/10.1186/s13071-017-2171-z.

682

683 Saleh, M.M.E., Hanounik, S.B., Al-muhanna, U.E., Al-dahir, H., Al-garrash, Z.H., 2001.

684 Distribution of Heterorhabditis indica (Nematoda: Heterorhabditidae) in eastern Saudi Arabia.

685 Int. J. Nematol. 11, 215-218.

686 
687 Salgado-Morales, R., Martínez-Ocampo, F., Obregón-Barboza, V., Vilchis-Martínez, K.,

688 Jiménez-Pérez, A., Dantan, E., 2019. Assessing the pathogenicity of two bacteria isolated from 689 the entomopathogenic nematode Heterorhabditis indica against Galleria mellonella and some 690 pest insects. Insects. 10. https://doi.org/10.3390/insects10030083.

691

692 San-Blas, E., Gowen, S., Pembroke, B., 2008. Steinernema feltiae: Ammonia triggers the 693 emergence of their infective juveniles. Exp. parasitol. 119. 180-5.

694 https://doi.org/10.1016/j.exppara.2008.01.008.

695

696 Sen-Selvan, J., Campbell, F., Gaugler, R., 1993. Density-Dependent Effects on

697 Entomopathogenic Nematodes (Heterorhabditidae and Steinernematidae) within an Insect Host.

698 J. Invertebr. Pathol. 62, 278-284. https://doi.org/10.1006/jipa.1993.1113.

699 Stamatakis, A., 2006. RAxML-VI-HPC: maximum likelihood-based phylogenetic analyses with

700 thousands of taxa and mixed models. Bioinformatics. 22, 2688-2690.

701 https://doi.org/10.1093/bioinformatics/btl446.

702

703 Stock, S.P., Rivera-Orduño, B., Flores-Lara, Y., 2009. Heterorhabditis sonorensis n. sp.

704 (Nematoda: Heterorhabditidae), a natural pathogen of the seasonal cicada Diceroprocta ornea

705 (Walker) (Homoptera: Cicadidae) in the Sonoran desert. J. Invertebr. Pathol. 100, 175-184.

706 https://doi.org/10.1016/j.jip.2008.11.011. 
708 Tamura, K., Stecher, G., Peterson, D., Filipski, A., Kumar, S., 2013. MEGA6: molecular

709 evolutionary genetics analysis version 6.0. Mol. Biol. Evol. 30, 2725-2729.

710 https://doi.org/10.1093/molbev/mst197.

711

712 Thanwisai, A., Tandhavanant, S., Saiprom, N., Waterfield, N.R., Ke Long, P., Bode, H.B.,

713 Peacock, S.J., Chantratita, N., 2012. Diversity of Xenorhabdus and Photorhabdus spp. and their

714 symbiotic entomopathogenic nematodes from Thailand. PLoS ONE, 7.

715 https://doi.org/10.1371/journal.pone.0043835.

716

717 Thomas, G.W., 1996. Soil pH and soil acidity, In: Sparks D.L. (Eds.), Methods of Soil Analysis:

718 Part 3. Chemical Methods, Agronomy Monograph. American Society of Agronomy-Soil Science

719 Society of America. Madison, Wisconsin. pp. 475-490.

720 https://doi.org/10.2136/sssabookser5.3.c16.

721

722 Thompson, J.D., Higgins, D.G., Gibson, T.J., 1994. CLUSTAL W: improving the sensitivity of

723 progressive multiple sequence alignment through sequence weighting, position-specific gap

724 penalties and weight matrix choice. Nucleic Acids Res. 22, 4673-4680.

725 https://doi.org/10.1093/nar/22.22.4673. 
727 Valencia-Agami, S.S., Cerqueda-García, D., Putzeys, S., Uribe-Flores, M.M., García-Cruz, N.U.,

728 Pech, D., Herrera-Silveira, J., Aguirre-Macedo, M.L., García-Maldonado, J.Q., 2019. Changes

729 in the Bacterioplankton Community Structure from Southern Gulf of Mexico During a Simulated

730 Crude Oil Spill at Mesocosm Scale. Microorganisms, 7.

731 https://doi.org/10.3390/microorganisms7100441.

732

733 Yooyangket, T., Muangpat, P., Polseela, R., Tandhavanant, S., Thanwisai, A., Vitta A., 2018.

734 Identification of entomopathogenic nematodes and symbiotic bacteria from Nam Nao National

735 Park in Thailand and larvicidal activity of symbiotic bacteria against Aedes aegypti and Aedes

736 albopictus. PLoS ONE, 13. https://doi.org/10.1371/journal.pone.019568 
Figure 1

Map of Yucatán state showing the sites sampled for entomopathogenic nematodes.

Sampling sites marked with red denote absence of EPNs, while sampling sites marked with blue and yellow were positive for EPNs.

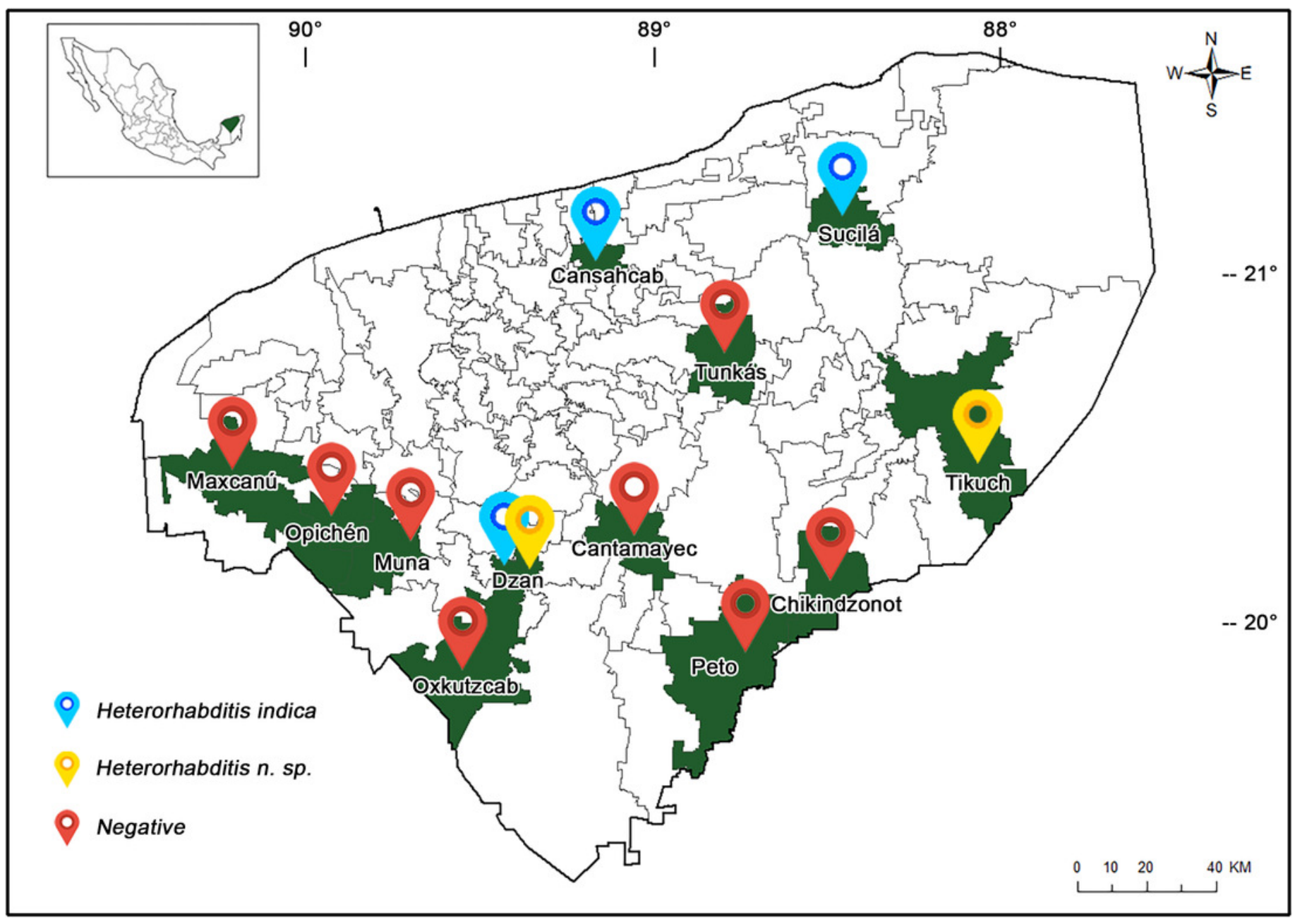




\section{Figure 2}

Phylogenetic relationships of species of the genus Heterorhabditis using the maximum likelihood method to generate the phylogenetic trees.

The tree obtained with ITS is shown on the left side and the resulting tree with $28 \mathrm{~S}$ is shown on the right side. The newly generated sequences are highlighted in bold. Numbers near the tree nodes represent the bootstrap support values and the scale bar indicates the number of substitutions per site.

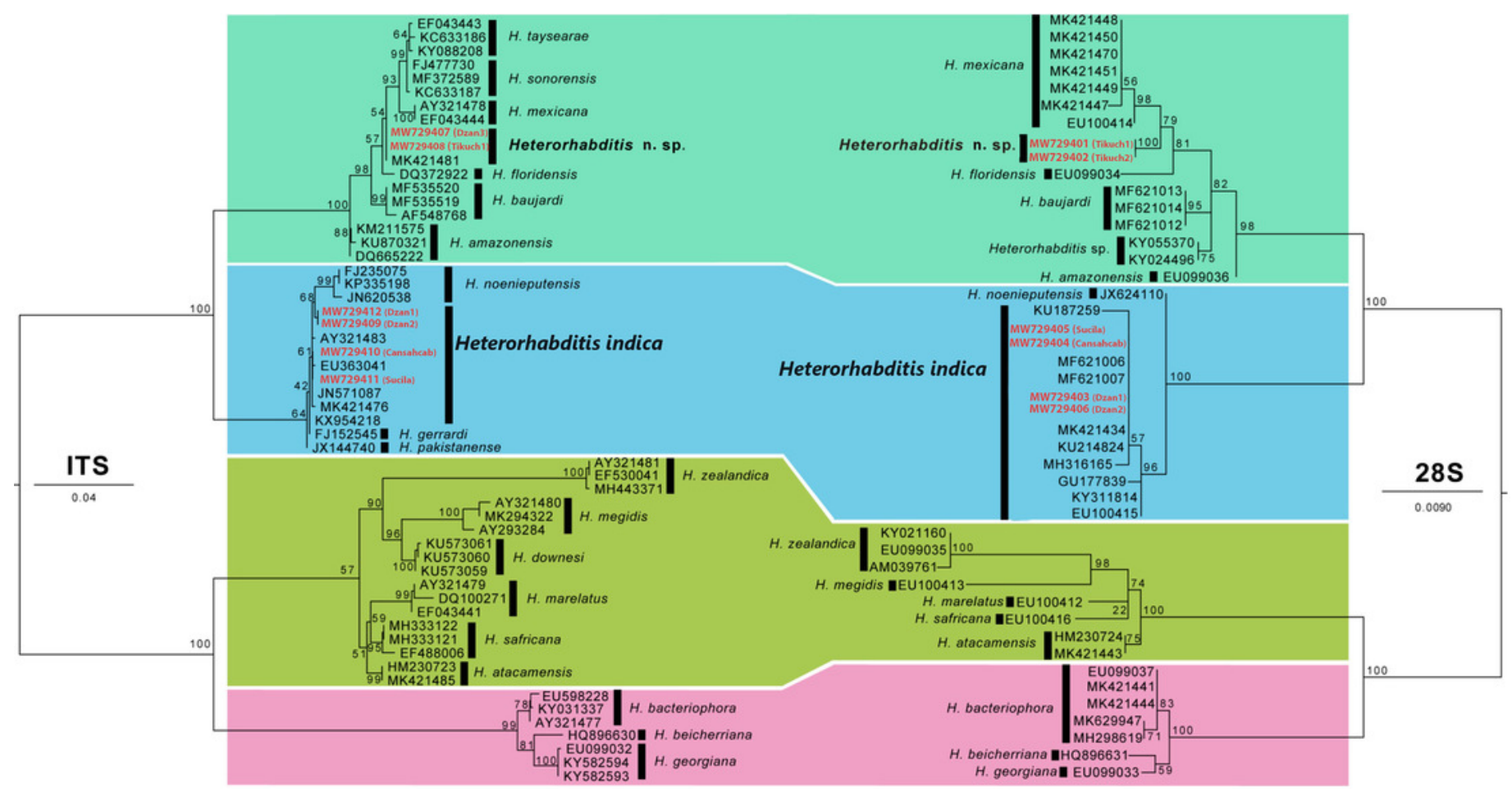


Figure 3

Kaplan-Meier overall survival curves comparing the mortality of Aedes aegypti larvae after exposure to infective juveniles of Heterorhabditis indica.

Control contained no infective juveniles. The treatments units were the number of infective juveniles of $H$. indica per mosquito larvae. Each treatment had 10 mosquito larvae.

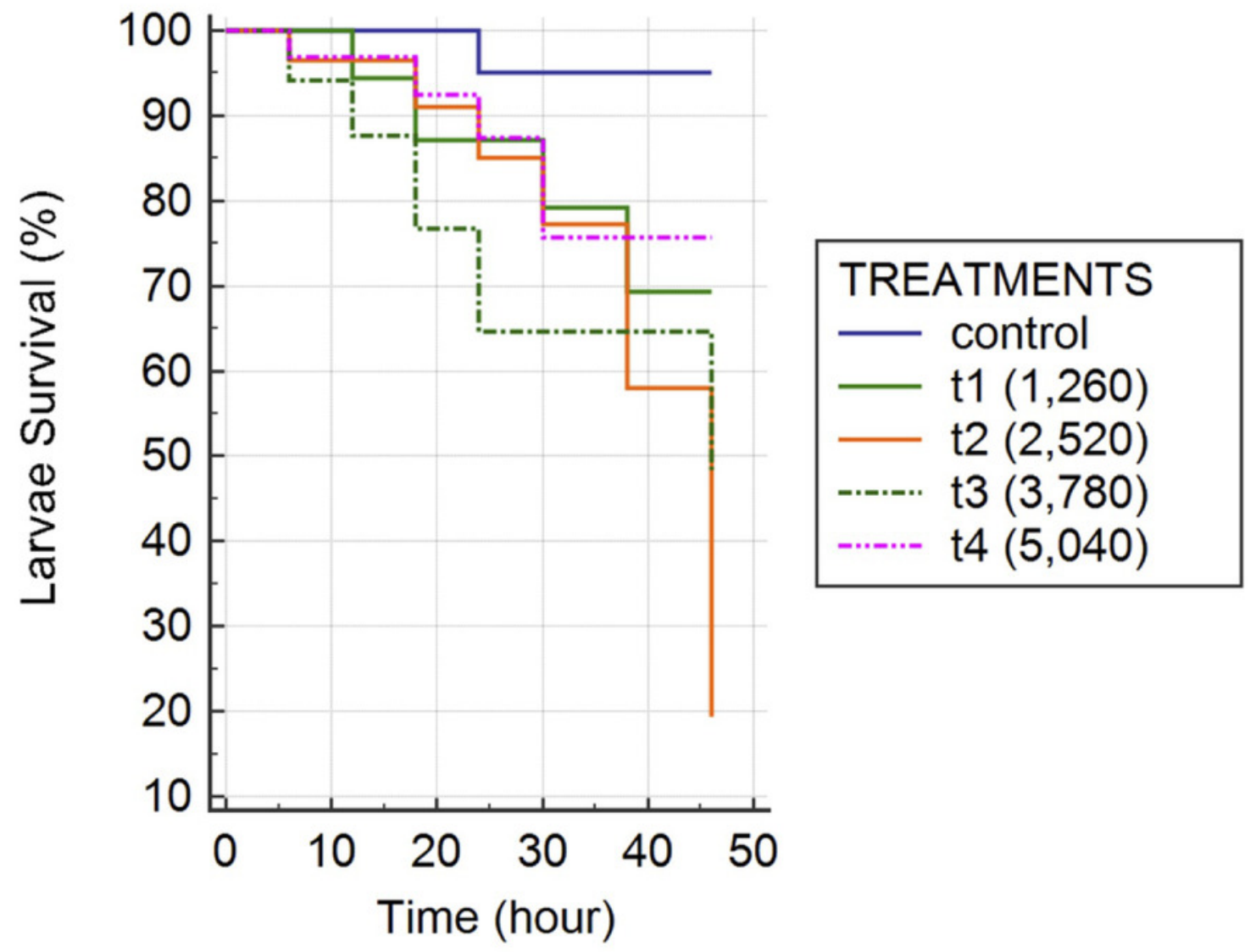




\section{Figure 4}

Relative abundance of bacteria in the larvae of Aedes aegypti infected with Heterorhabditis indica.

The colours represent the bacterial diversity of the genera present in the mosquito larvae. Acronyms were as follows: C-Larva: mosquito larvae from the control treatment without nematodes; T2-Larva: mosquito larva from treatment two (2,520 infective juveniles of Heterorhabditis indica per mosquito larva).

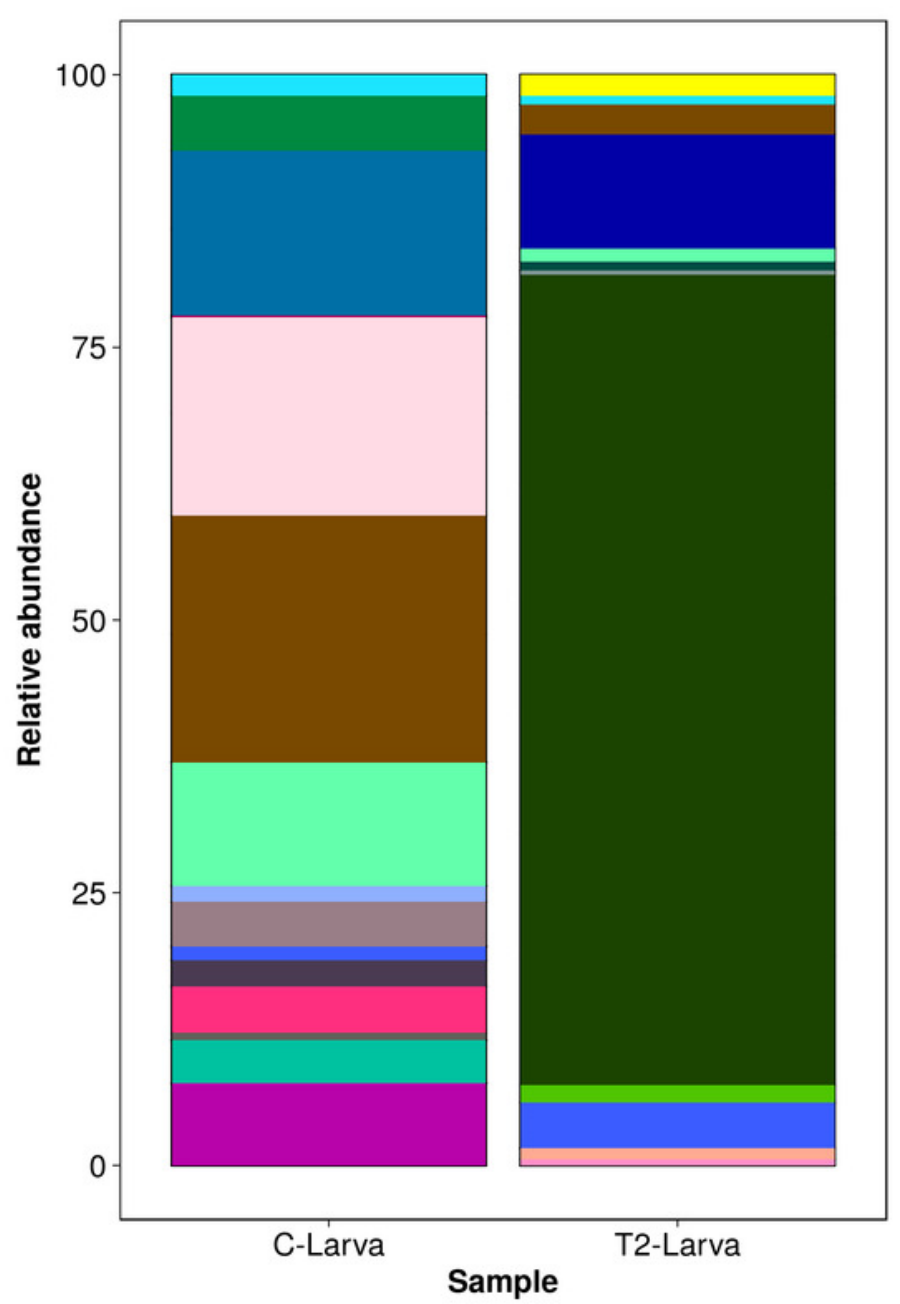

\section{Genus}

Achromobacter

Acinetobacter

Allorhizobium-Neorhizobium-Pararhizobium-Rhizobium

Altererythrobacter

Aquabacterium

Brevundimonas

Candidatus Alysiosphaera

Chryseobacterium

Delftia

Elizabethkingia

Flavobacterium

Hyphomicrobium

Lysinibacillus

Methyloversatilis

Microbacterium

Mycobacterium

Paenibacillus

Photorhabdus

Phreatobacter

Pseudomonas

Pseudoxanthomonas

Rheinheimera

Sediminibacterium

Sphingobacterium

Sphingobium

Sphingomonas

Stenotrophomonas

Taibaiella

Unassigned

Variovorax 


\section{Table $\mathbf{1}$ (on next page)}

Mean of the measured soil parameters with the presence and absence of EPNs from Yucatán state. 


\begin{tabular}{|c|c|c|c|c|c|c|c|c|c|}
\hline Genus/Species & Locality & $\begin{array}{l}\text { Geographic } \\
\text { coordinates }\end{array}$ & Soil type & $\begin{array}{c}\text { Organic } \\
\text { matter (\%) }\end{array}$ & $\mathrm{pH}$ & Land use & $\begin{array}{l}\text { Potassium } \\
(\mathrm{Cmol}(+) / \mathrm{kg})\end{array}$ & $\begin{array}{c}\text { Calcium } \\
(\mathrm{Cmol}(+) / \mathrm{kg})\end{array}$ & $\begin{array}{l}\text { Phosphorus } \\
\text { (mg/kg) }\end{array}$ \\
\hline H. indica & Cansahcab & $\begin{array}{l}21^{\circ} 9^{\prime} 16.02^{\prime \prime} \mathrm{N} \\
89^{\circ} 5 \text { '26.36" O }\end{array}$ & Sandy clay loam & 12.7 & 8.0 & Cattle farm & 1.5 & 53.8 & 133.6 \\
\hline H. indica & Sucila & $\begin{array}{c}21^{\circ} 8^{\prime} 58.98 " \mathrm{~N} \\
88^{\circ} 18^{\prime} 22.04^{\prime \prime} \mathrm{O}\end{array}$ & Sandy clay loam & 7.5 & 7.9 & Cattle farm & 2.3 & 24.6 & 89.9 \\
\hline $\begin{array}{c}\text { H. indica / } \\
\text { Heterorhabditis } \\
\text { n. sp. }\end{array}$ & Dzan & $\begin{array}{l}20^{\circ} 22^{\prime} 36.1 " \mathrm{~N} \\
89^{\circ} 27^{\prime} 2.6^{\prime \prime} \mathrm{O}\end{array}$ & Sandy clay loam & 5.1 & 7.8 & Field crop & 14.7 & 80.2 & 1.6 \\
\hline $\begin{array}{l}\text { Heterorhabditis } \mathrm{n} . \\
\mathrm{sp} .\end{array}$ & Ticuch & $\begin{array}{l}20^{\circ} 42^{\prime} 5.82^{\prime \prime} \mathrm{N} \\
88^{\circ} 6{ }^{\prime} 39.07^{\prime \prime} \mathrm{O}\end{array}$ & Sandy loam & 8.5 & 7.2 & Cattle farm & 0.3 & 17.0 & 0.02 \\
\hline Without EPNs & Maxcanu & $\begin{array}{l}20^{\circ} 35^{\prime} 34.311^{\prime \prime} \mathrm{N} \\
89^{\circ} 59^{\prime} 15.91^{\prime \prime} \mathrm{O}\end{array}$ & Sandy loam & 9.6 & 7.5 & Industrial & 2.5 & 43.3 & 58.6 \\
\hline Without EPNs & Opichen & $\begin{array}{c}20^{\circ} 33^{\prime} 17.34^{\prime \prime} \mathrm{N} \\
81^{\circ} 51^{\prime} 51.50 “\end{array}$ & Sandy loam & 9.1 & 7.8 & Forestry & 3.0 & 46.0 & 801.1 \\
\hline Without EPNs & Muna & $\begin{array}{l}20^{\circ} 29^{\prime} 16.34 " \mathrm{~N} \\
89^{\circ} 43^{\prime} 36.18^{\prime \prime} \mathrm{O}\end{array}$ & Sandy loam & 12.4 & 7.4 & Industrial & 2.2 & 37.8 & 4.1 \\
\hline Without EPNs & Oxkutzcab & $\begin{array}{r}20^{\circ} 19^{\prime} 1.00^{\prime \prime} \mathrm{N} \\
89^{\circ} 25^{\prime} 52.79^{\prime \prime} \mathrm{O}\end{array}$ & Clay & 4.8 & 7.4 & Citric crop & 1.5 & 15.6 & 38.2 \\
\hline Without EPNs & Tunkas & $\begin{array}{l}20^{\circ} 54^{\prime} 5.45^{\prime \prime} \mathrm{N} \\
88^{\circ} 44^{\prime} 41.77^{\prime \prime} \mathrm{O}\end{array}$ & Sandy loam & 9.5 & 7.8 & Field crop & 1.5 & 52.4 & 2430.5 \\
\hline Without EPNs & Chikindzonot & $\begin{array}{l}20^{\circ} 19^{\prime} 39.40^{\prime \prime} \mathrm{N} \\
88^{\circ} 29^{\prime} 23.66^{\prime \prime} \mathrm{O}\end{array}$ & Clay & 5.7 & 7.9 & Forestry & 2.3 & 30.2 & 0.3 \\
\hline Without EPNs & Peto & $\begin{array}{l}20^{\circ} 06^{\prime} 25.4^{\prime \prime} \mathrm{N} \\
88^{\circ} 52^{\prime} 45.6^{\prime \prime} \mathrm{O}\end{array}$ & Clay & 8.1 & 7.6 & Forestry & 1.7 & 33.4 & 2.2 \\
\hline Without EPNs & Cantamayec & $\begin{array}{c}20^{\circ} 28^{\prime} 38.40^{\prime \prime} \mathrm{N} \\
89^{\circ} 44^{\prime} 43.62^{\prime \prime} \mathrm{O}\end{array}$ & Sandy loam & 0.8 & 7.7 & Field crop & 0.5 & 26.1 & 1.3 \\
\hline
\end{tabular}




\section{Table 2 (on next page)}

Mean difference between EPN positive and EPN negative soil samples parameters. 


\begin{tabular}{|c|c|c|c|c|c|c|c|c|c|}
\hline Parameter & Group 1 & Group 2 & N1 & N2 & Mean (1) & Mean (2) & Mean (1) - Mean (2) & $T$ & $P$ value \\
\hline $\begin{array}{c}\text { Phosphorus } \\
\text { (mg/kg) }\end{array}$ & EPNs & $\begin{array}{l}\text { Without } \\
\text { EPNs }\end{array}$ & 16 & 40 & 70.37 & 417.07 & -346.70 & -1.95 & 0.0575 \\
\hline $\begin{array}{c}\text { Organic matter } \\
(\%)\end{array}$ & EPNs & $\begin{array}{l}\text { Without } \\
\text { EPNs }\end{array}$ & 16 & 40 & 8.48 & 7.55 & 0.93 & 0.87 & 0.3906 \\
\hline Sand $(\%)$ & EPNs & $\begin{array}{l}\text { Without } \\
\text { EPNs }\end{array}$ & 16 & 40 & 45.99 & 42.29 & 3.70 & 0.70 & 0.4889 \\
\hline Silt (\%) & EPNs & $\begin{array}{l}\text { Without } \\
\text { EPNs }\end{array}$ & 16 & 40 & 15.63 & 16.45 & -0.82 & -0.41 & 0.6830 \\
\hline Clay (\%) & EPNs & $\begin{array}{l}\text { Without } \\
\text { EPNs }\end{array}$ & 16 & 40 & 38.39 & 41.26 & -2.88 & -0.56 & 0.5752 \\
\hline $\begin{array}{l}\text { Potassium } \\
(\mathrm{Cmol}(+) / \mathrm{kg})\end{array}$ & EPNs & $\begin{array}{l}\text { Without } \\
\text { EPNs }\end{array}$ & 16 & 40 & 5.86 & 1.94 & 3.92 & 2.50 & 0.0247 \\
\hline $\mathrm{pH}$ & EPNs & $\begin{array}{l}\text { Without } \\
\text { EPNs }\end{array}$ & 16 & 40 & 7.88 & 7.69 & 0.19 & 2.43 & 0.0183 \\
\hline $\begin{array}{c}\text { Calcium } \\
(\mathrm{Cmol}(+) / \mathrm{kg})\end{array}$ & EPNs & $\begin{array}{l}\text { Without } \\
\text { EPNs }\end{array}$ & 16 & 40 & 50.64 & 35.65 & 14.99 & 2.29 & 0.0337 \\
\hline
\end{tabular}




\section{Table 3 (on next page)}

Percentage survival values of Aedes aegypti mosquito larvae exposed to entomopathogenic nematodes Heterorhabditis indica.

The acronyms were as follows: $\mathrm{SE}=$ standard error; $95 \% \mathrm{Cl}$ for the mean $=95 \%$ confidence intervals (CI) for control and treatments (T1-T4); I/[IJs = mosquito larvae/infective juveniles. 
1

\begin{tabular}{ccccc}
\hline Factor & Mean & SE & 95\% CI for the mean \\
\hline $\begin{array}{c}\text { Control }(\text { no } \\
\text { nematodes })\end{array}$ & 44.900 & 1.072 & $42.799-47.001$ \\
T1 $(1: 1,2601 / \mathrm{IJs})$ & 40.016 & & \\
T2 $(1: 2,5201 / \mathrm{IJs})$ & 38.954 & 2.757 & $34.612-45.420$ \\
T3(1: $3,7801 / \mathrm{IJs})$ & 35.710 & 2.640 & $33.780-44.128$ \\
T4 $(1: 5,040$ 1/IJs $)$ & 40.524 & 2.814 & $30.195-41.225$ \\
\hline
\end{tabular}

2

3 


\section{Table 4 (on next page)}

Fifty percent lethal dose values (LD50) for $\mathrm{H}$. indica against mosquito larvae third stage at different exposure times. 


\begin{tabular}{c|c|c}
\hline $\begin{array}{c}\text { Exposure time } \\
(\mathrm{hr})\end{array}$ & LD50 (IJs/mosquito larvae) & \\
\hline 12 & 14,997 & $11,545-19,481$ \\
24 & 7,040 & $5,802-8,277$ \\
48 & 6,324 & $5,189-7,458$ \\
\hline
\end{tabular}

3 